Vol. LV - REVISTA DE HISTÓRIA - Ano XXVII

C O N F E R E N C I A

\title{
O INDIO BRASILEIRO: IMAGEM E REALIDADE
}

\author{
EGON SCHADEN \\ da Universidade de São Paulo.
}

As imagens e os estereótipos étnicos não existem à margem da realidade histórica. Fazem parte dela. Assim, o binômio imagem e realidade sugere desde logo um problema que, apesar de trivial, é não raro esquecido nas discussões sobre o conceito, ou melhor, os conceitos que do aborígine brasileiro se formaram no correr do tempo. A oposição entre imagem e realidade, ainda que legítima en teoria, não há de ser colocada em termos tais que se abandone a perspectiva do contexto histórico responsável pela emergência das idéias que os grupos étnicos têm uns dos outros e segundo as quais se pautam as relações entre eles. Para compreender os estereótipos, como, aliás, todo gênero de representações coletivas, cumpre ter em mente que, por esdrúxulos que às vezes possam parecer, eles nunca se reduzem a simples criações do espírito. São produtos da mentalidade de uma época, de uma situação histórica peculiar, dos representantes de uma categoria social ou de um grupo cultural. Uma vez incorporados a um sistema de idéias, convertem-se $\mathrm{em}$ fatores que condicionam e, até certo ponto, determinam as atitudes e o compor-tamento diante dos membros das respectivas etnias.

Talvez se estranhe que esta verdade, corriqueira para o antropólogo, como, por certo, para qualquer estudioso das ciências humanas, seja aqui lembrada. Mas é que facilmente nos desorientam as discrepâncias que à primeira vista julgamos deparar no afã de estabelecer correlações unívocas e precisas entre certos aspectos do problema indígena brasileiro e os estereótipos presentes, em diferentes épocas e lugares, na trama das relações entre o homem branco e os primitivos naturais da terra.

E fácil compreender, por exemplo, que, para o colono dos primeiros séculos, assim como para o latifundiário de ontem ou de hoje, o silvícola tenha sido ou seja, conforme o caso, ao princípio um 
estorvo e a seguir um elemento a ser explorado, e que destes pontos de vista se configure e transfigure a imagem do índio. Também nos parece natural que missionários de outrora, imbuídos de espírito messiânico e empenhados na salvação das almas, hajam encontrado em sua doutrina critérios para julgar o que se lhes afigurava como natureza diabólica de determinadas crenças e práticas indígenas, a única explicação para o estado de depravação em que, a seu ver, se encontrava o gentio. $E$ assim por diante. $O$ que, no entanto, nos pode causar surpresa é o grau em que persistem, pelos tempos afora, em contraste com a experiência, para não dizer com o bom senso, os preconceitos, as distorções e as caricaturas. E de fato ficaríamos surpreendidos se não recordássemos, para compreender o fenômeno, a inércia do espírito humano ante a conveniência, sugerida pela razão, de abandonar idéias falsas, ainda mais quando estas se apoiam em atitudes subjetivas e se mantêm vivas e virulentas pelo jogo das reações emocionais, sempre mais fortes do que o entendimento.

Desde logo se verifica o quanio seria ilusória a busca de uma perspectiva que revelasse linhas claramente discerníveis, segundo as quais se teria constituído e, aos poucos, transformado a imagem do índio brasileiro de acordo com a sequêencia das fases históricas da vida política, social e econômica desde os dias do descobrimento até a atualidade. Seria ilusória, antes de mais nada, porque as relações do homem civilizado com o indígena sempre se estabeleceram em diferentes níveis e com a interferência de interesses e propósitos às vezes diametralmente opostos. E esta a razão pela qual em todas as épocas existiram, lado a lado, conceitos variados e até contraditórios do gentio da terra, ocupando toda uma escala de imagens: num dos extremos, a idéia do silvícola feroz, traiçoeiro, preguiçoso e estúpido; no outro, a figura idealizada de uma criatura a muitos títulos superior, em seus modos de vida e em sua maneira de ser, ao cristão civilizado. Se é verdade que todas essas imagens, quer as positivas, envoltas quiçá num halo de poesia romântica, quer as negativas, geradas pelo desprezo etnocêntrico, umas e outras notoriamente falsas, são, apesar de tudo, frutos de vivências histórico-culturais, não havemos de ignorar por isso que todas elas tiveram sempre características de autênticos mitos. Como tais é preciso encará-las e como tais o antropólogo deve levá-las a sério, se é que pretende que a imagem por ele próprio elaborada, dentre todas a que até hoje menos tem influído na realidade concreta, venha efetivamente um dia, antes que seja tarde, desempenhar o papel que se requer do conhecimento científico na sociedade moderna.

Quanto aos retratos negativos do índio brasileiro, vistos em perspectiva diacrônica através destes quase cinco séculos, afigura-se vá- 
lido distinguir, em princípio, duas categorias. À primeira corresponde a imagem depreciativa nascida de preconceitos etnocêntricos do homem civilizado, ou seja, de sua atitude sobranceira ante as populações tribais, todas elas tidas de antemão como bárbaras e selvagens; à segunda, o conceito que se refere ao índio em contacto regular ou em convívio com o mundo dos brancos, ora mais, ora menos sujeito a inevitáveis influências desorganizadoras, já não sendo, por isso, capaz de viver satisfatoriamente segundo os seus padrões tradicionais, nem havendo conseguido, por outro lado, adaptar-se às exigências, reais ou supostas, da nova situação. Em outros termos: a "depravação" que se julgava divisar no índio em seu primitivo estado era devida à projeção de conceitos e valores europeus no juízo que se fazia dos índios não beneficiados, na opinião do branco, pelo bafejo da civilização; a que depois se pintou foi a caricatura de um índio realmente atormentado por problemas que começaram a surgir no momento em que a civilização o fez entrar em sua órbita. Em muitos casos, como é compreensível, as duas imagens acabaram por fundir-se numa só, dando origem à convicção de que o silvícola é um ente inferior, irremediavelmente condenado a ser indolente, irresponsável, perverso e refratário a idéias e valores considerados pelo branco como expressão de um estádio mais elevado da existência do homem.

A noção da ferocidade animal do gentio e tudo o que ela implica, inclusive a duvidosa natureza humana do índio, nasceu, logo no início do século XVI, em parte por causa de reações agressivas - ou, mais objetivamente, defensivas - contra o colono que viera perturbar, com a sua presença e os seus interesses, o equilíbrio da vida tribal, procurando explorar o silvícola a pô-lo a seu serviço, muito mais pela força do que pela persuasão, e em parte como decorrência da estupefação ante o que, na maneira de ser e de viver do índio, aparecia ans olhos do europeu como demasiado grotesco e repugnante para coadunar-se com a sua concepção de um ente dotado de discernimento $\mathrm{c}$ de juízo moral. Mais tarde, essa idéia ia sobreviver no espírito do sertanejo, sempre alimentada pelo pavor que a este incutia a presença de tribos bravias. Reciprocamente, e bem sabemos porquê, o índio tinha o branco por selvagem feroz. Caso não pudesse ser amansado, outra solução não havia senão trucidá-lo.

Quando os primeiros europeus aportaram no Brasil, persistia ainda no Velho Mundo a tradição medieval de criaturas para-humanas. Por que não haveriam os índios de pertencer a este gênero de humanidade frustrada? E significativo a este respeito o que Vaz de Caminha escreve ao Rei D. Manuel sobre os Tupinikín do Sul da Bahia. A insistente benevolência com que os retrata deixa transparecer, ao que parece, alguma surpresa por haver encontrado nestas lon- 
gínqüas paragens o que por certo não teria esperado encontrar: gente que em nada se distingüia de verdadeiros homens. Sabemos o quanto a Europa relutou em aceitar esta evidência, sem embargo da categórica definição papal de Paulo III em sua Letra Apostólica de 2 de junho de 1537, a bula Sublimis Deus, mais conhecida como Veritas ipsa, que é como se inicia o parágrafo relativo aos naturais das Américas (1). Como que estupefato, anota, por exemplo, Henri Estienne, autor quinhentista, referindo-se aos sete Tupinambá que desfilaram na fête brésilienne de Rouen, no ano de 1550, que esses índios "falam pela boca". Não se lembra o pobre homem de acrescentar: "e pensam com a cabeça". Informa, porém, que "andam nus e não têm nenhuma religião". E, mais, que "desconhecem o pão, o vinho e o dinheiro", ignorância esta que, para o francês daquele tempo, devia ser índice de lamentável atraso mental (2). Mas, como adverte Afonso Arinos de Melo Franco, as observações sobre a ausência de religião, a nudez e o desconhecimento do dinheiro serviriam mais tarde para fundamentar a teoria da bondade natural, que iria florescer no século XVIII (3). Para os filósofos não era, afinal, tão difícil convertê-las em argumentos a favor da tese oposta. Só que esta tese, embora aceita por muitos, foi historicamente menos eficaz no trato que os brancos tiveram com os indígenas.

O que mais surpreende, porém, é a tenacidade com que a idéia do silvícola intrinsicamente inferior vem persistindo, pelos séculos afora, até os nossos dias. Seria explicável a sua sobrevivência entre o povo inculto e rude do sertão, mas é que a encontramos também no cérebro de provectos homens de ilustração e de estudo, dos quais se esperaria juízo mais objetivo. Se lemos em Fernão Cardim, para citar apenas um dentre inúmeros autores antigos,

"por milagre tenho o domar-se gente tão fera" (4),

nos inclinamos a dizer que isto vai por conta do horizonte intelectual do tempo, ainda que o mesmo século XVI, como é notório, tenha deixado também retratos bem diferentes, e alguns muito positivos, do gentio da terra, a começar pela idílica descrição de Vaz de Caminha. Poder-se-ia escrever volumes inteiros sobre os preconceitos de historiadores, juristas, homens públicos e até antropólogos destes últimos cem anos, cuja mente se revelou impermeável à evidência. Ou seja, de um hermetismo a toda prova.

(1). - Veja-se o texto dessa bula em apênđice a NóBREGA, 1954. págs. $105-106$.

(2). - Apud MELO FRANCO, 1937, págs. 66-67.

(3). - Op. cit., pág. 67.

(4). - CARDIM, 1939, pág. 271. 
Até o Visconde de Porto Seguro, merecedor da maior admiração por sua obra de pesquisador consciencioso e competente, tido como o maior historiador do Brasil no século passado, escreveu coisas como esta:

"Eram falsos e infiéis; inconstantes e ingratos, e bastante desconfiados. Além de que: desconheciam a virtude da compaixão $(\ldots)$. Nem tinham idéias de sã moral; isto é, da que nasce dos sentimentos do pudor e da sensibilidade, da moral que respeita o decoro e a boa fé; e eram dotados de uma quase. estúpida brutalidade, e difíceis de abalar-se de seu gênio fleugmático" (5).

No caso, nem sequer haveria como explicar pelo espírito da época o ranço dessas idéias, já que, além da voga de idealização romântica do silvícola por literatos coevos, começavam aos poucos a firmar-se naqueles anos os trabalhos antropológicos em nossa terra, não só no Museu Nacional, como também no Instituto Histórico e Geográfico Brasileiro e em outros grêmios científicos. Além disso, há o paradoxo de o próprio Varnhagen haver sido em seus dias um dos que mais incentivaram o estudo dos idiomas indígenas.

Como sabemos, não se fizeram esperar os protestos contra tão estranha descrição do índio brasileiro, entre eles o de D. J. Gonçalves de Magalhães, ainda em viđ̣a do eminente autor (6). Algo, entretanto, que de modo constrangedor e muito a contragosto, nos leva a fazer um reparo é que, nas eruditas notas com que enriqueceram a 4a edição da monumental História Geral do Brasil, Rodolfo Garcia e Capistrano de Abreu, notáveis conhecedores da etnologia brasileira, passam com toda a complacência por sobre a rudeza com que Varnhagen caracteriza o gentio. Pouco ou nada tentam para desfazer a impressão que os conceitos do Visconde deixam no espírito do leitor.

Ainda em princípios de nosso século, às vésperas da fundação de Serviço de Proteção aos Indios, houve o triste escândalo provocâdo por Hermann von Ihering, Diretor do Museu Paulista, que, escrevendo sobre os índios então ainda bravios do Brasil Meridional, os considerava tão selvagens e incapazes de superar a sua ferocidade que chegou ao ponto de sugerir o seu extermínio pela violência (7) . Dir-se-ia que depois da indignação geral contra essa atitude já não haveria, pelo menos entre os intelectuais, quem aceitasse o este-

(5). - PORTO SEGURO, pág. 52.

(6). - MAGALHÃES, 1860.

(7). - VON IHERING, 1907, pág. 215. 
reótipo do silvícola estúpido e indomável. Puro engano. No ano da graça de 1946, um ilustre professor de Direito Internacional publica em São Paulo um livro intitulado Os Selvagens Americanos perante $O$ Direito, (8), no qual, referindo-se aos "indígenas belicosos do Brasil Meridional", declara haver von Thering fornecido amostras de

"manifestações de seus instintos sangüinários e de sua selvajaria natural" (9).

A certa altura, o autor, membro da Academia Brasileira de Letras, se refere aos mitos indígenas como a frutos de inspiração poética

"rudimentar e infantil", "sem poesia e sem imaginação" (10).

Num dos passos reconhece, é verdade, que

"essa raça não era inteiramente bárbara, nem incapaz de produzir e criar" (11),

informando que Hans Staden

"conta anedotas que dizem bastante sobre a inteligência dos índios" (12),

mas afinal o "vislumbre de alguma inteligência" se percebia em apenas uma parte das tribos, já que

"outras, de naturezá mais bárbara e selvagem, se apresentavam refratárias ao comércio com quaisquer outros povos e incapazes mesmo de se fixar em alguma região, preferindo embrenhar-se pelas florestas" (13).

Em resumo, esses pobres diabos, cuja família era constituída

“à feição de seus instintos" (14), viviam "como verdadeiros animais" (sic!),

o que, aliás, não admira, pois, acredita o notável jurista, hoje se conhecem,

(8). - O texto se baseia num curso realizado em 1930 pelo autor, Ro drigo Otávio Langardi de Menezes, na Academia de Direito Internacional de Haia. Foi primeiro publicado em francês no ano de 1931. A edição brasileira saiu bastante ampliada. V. OTÁVIO, 1946.

(9). - OTÁVIO, 1946, pág. 170.

(10). - Op. cit., pág. 168.

(11). - Op. cit., pág. 164.

(12). - Ibidem.

(13). - Op. cit., pág. 166.

(14). - $O p$. cit., pág. 168. 


\begin{abstract}
"perfeitamente, a insuficiência intelectual e as falhas de sua vontade" (15).
\end{abstract}

Não nos agastemos, porém, com esses absurdos, contra os quais o antropólogo só pode reagir com uma ação sistemática de esclarecimento dos ignorantes, como dós doutos. E também, em certos casos, de homens prestigiosos na esfera política, para que não se repita, por exemplo, o que se lê, preto sobre branco, assinado pelo então Governador de Santa Catarina, quando, na apresentação de um volume comemorativo do centenário da fundação de Blumenau, não encontra, para caracterizar o indígena, outro adjetivo senão este: "felino" (16).

Doloroso é registrar a constância com que esses preconceitos se perpetuam também em livros escolares, que não vamos aqui passar em revista, e até, como há pouco foi denunciado por Sílvio Coelho dos Santos, numa publicação que se diz destinada a turistas que pretendam visitar a região das antigas missões jesuíticas do Rio Grande do Sul. Cito, sem comentários:

"O índio, por sua natural indolência, volubilidade e imprudência, mal os jesuítas o deixavam um pouco à vontade, voltava ao estado primitivo ( ...). Assim, os missionários (...) entre esses seres atrasadíssimos e num País ainda selvagem $(\ldots)$. E entre os Guaraní e outras tribos reinava a poligamia. O filho seguia a condição do pai e a mulher era escrava do homem (...)" (17).

Pergunto apenas: Quem diria que isto se imprimiu em 1973?

Todos esses juízos racistas e para-racistas se referem, em essência, ao índio bravio, ao silvícola, diríamos, ainda em estado natural, se a expresão não nos sugerisse a falsa oposição entre este e o estado de cultura. Igualmente perniciosos e não menos difíceis de extirpar são os conceitos negativos que pretendem caracterizar o indígena semi-aculturado, vítima dos efeitos da civilização e, por conseguinte, marginal com relação a sua cultura de origem e também à dos brancos. Embora sejam caricaturais esses retratos das tribos que se encontram em algum ponto do caminho entre a antiga existência tribal comunitária e a vida civilizada - ou, como tem sido a regra, a extinção -, precisamos convir em que muitos de seus traços não de-

(15). - Op. cit., pág. 174.

(16). - Vários autores, Centenário de Blumenau.

(17). - Brazilisso LEITE, Generalidade das Missões Jesuiticas, 1531 -1759, Porto Alegre, 1973, págs. 30 e 33, cit. por COELHO DOS SANTOS, 1975, pág. 80 . 
vem ser descartados como simples invencionices. E trivial que 0 processo aculturativo do gentio gera sempre um estado de depauperamento cultural, de desorganização social e de conturbação psíquica. Os problemas que isto representa, longe de fictícios, são pungentemente reais. Seria insensato negá-los ou não dar-lhes a devida importância, pois neles está o ponto nevrálgico que os intentos de uma antropologia aplicada hão de pôr em mira.

E a esses aspectos que se costumam aferrar, distorcendo-os, os que traçam o perfil do índio semi-aculturado: sujo e maltrapilho, preguiçoso, traiçoeiro, ladrão, cachaceiro e não sei o que mais. E se este conceito se revela tão resistente, é, em grande parte, devido a sua função de justificativa para o tratamento indigno a que, nem sempre, mas com frequiência, o índio está exposto em suas relações com os patrões brancos.

Ora, também essa categoria de estereótipos negativos se veio constituindo desde as primeiras décadas do período colonial. As suas origens remontam às dificuldades surgidas com a ingênua pretensão de, a curto prazo, integrar o homem das selvas no mundo da civilização. Em vez de "elevá-lo", como se esperava, ao nível do colono, verificou-se a sua maior ou menor degradação, ou seja, a sua rápida e quase sempre irremediável decadência física e cultural. Suponho não caber censura a esta maneira franca de dizê-lo, porquanto, se, como antropólogos, queremos ser úteis, cumpre-nos em primeiro lugar ser realistas. Não era preciso, nem para os colonos e os colonialistas dos séculos XVI e XVII, nem para os missionários, muita sagacidade para descobrirem que todas aquelas manifestações deprimentes do silvícola colhido nas malhas da administração portuguesa nos trópicos, em lugar de desaparecerem com o tempo, que dizem ser o melhor remédio para todos os males, iam, antes, agravando-se a olhos vistos. Só que em geral o europeu, sobranceiro e etnocêntrico, e, mais tarde, os seus descendentes, teimaram em fechar os olhos à evidência de haver sido a situação por eles criada, e não a pretensa incapacidade inata do índio, a responsável pela triste condição a que se viam reduzidos os antigos donos desta terra.

Há, pois; de qualquer modo, um grão de verdade, que seria ingênuo deixar de reconhecer, num dos aspectos da chamada teoria da decadência dos índios, exposta, sem rebuços e com sentimento de decepção, por um grande sábio, Karl Friedrich Philipp von Martius, já na primeira metade do século XIX, ou, mais precisamente, em 1838 (18). Assinale-se, entretanto, que von Martius,

(18) . - "Die Vergangenheit und Zukunft der amerikanischen Menschheit", conferência feita em Friburgo, num congresso de naturalistas e médicos alemães, em 18 de setembro de 1838. Em: VON MARTIUS, 1867, págs. 1-42. 
tido com justiça como o "pai da etnologia brasileira", remonta a tempos proto-históricos a decadência do aborígine das Américas, de modo que, em seu entender, a presença do europeu nada mais fez do que acelerar um processo já em pleno curso quando se descobriu o Novo Mundo. Hoje, é claro, ninguém mais aceitaria tal explicação.

E curioso e eloqüente, porém, o fato de que pouco antes de von Martius, um autor seu conterrâneo, que não tinha pretensão a cientista, que era escritor medíocre e cujo texto nada mais é do que um conjunto de "retratos falados" a título de complemento a uma série de desenhos artísticos feitos durante uma estada no Brasil, coloca o problema em termos mais realistas, sem, o que dele tambén não se exigiria, romper a couraça de umas tantas prevenções que the tolhiam o horizonte mental. O testemunho é significativo sobretudo por ser o de um simples burguês da época, e não o de um intelectual, nem o de um cidadão interessado na exploração econômica do índio. Refiro-me a Johann Moritz Rugendas, artista bávaro, que, em sua Viagem Pitoresca através do Brasil, publicada nos anos de 1827 a 1835 , nos legou um acervo interessantíssimo e muito vivo, embora de fidelidade em parte discutível, de aspectos da vida brasileira de sua época. Ora, Rugendas, sem ser rousseauniano, percebeu muito bem que foi a civilização que estragou o índio. E Rugendas foi, salvo engano, o primeiro que nos deu, e com admirável singeleza, um perfil do índio culturalmente desarraigado, um perfil que tem as suas inevitáveis distorções, mas no qual se lobriga a compreensão intuitiva do que há de essencial em toda crise aculturativa, mais de um século antes de esta expressão se haver firmado no vocabulário da ciência.

Com cores bastante sombrias pinta Rugendas o estado deplorá. vel dos índios brasileiros de seu tempo. Em sua descrição se deparam frases como esta:

"Essa indolência, e a sua insensibilidade diante de tudo o que não se prende à vida animal, são tão grandes que o observador mais imparcial e mais filantrópico é às vezes levado a duvidar da possibilidade de melhorar a existência grosseira dessas criatu. ras, mergulhadas no embrutecimento" (19).

Mas é de notar que o tradutor do texto entendeu bem que a idéia do original era a de "embrutecimento" e não de "brutalidade", que é coisa bem diversa. E, ainda, que tanto "a profunda indolência, que", segundo o autor,

(19). - RUGENDAS, 1940, pág. 102. 
"constitui, atualmente, o traço principal dos indigenas" (20),

e os demais elementos negativos que neles aponta não são, para ele, devidos a uma inferioridade racial. Baseado nos relatos de antigos viajantes, admite que à chegada dos primeiros europeus teriam os aborígines tido um estado de cultura superior e que, não fosse a ação de interferências estranhas e nefastas, eles teriam prosseguido no caminho do progresso, não no rumo da civilização européia, mas de outra, mais de acordo com a sua natureza (21). Para Rugendas, o triste estado a que haviam chegado ia, pois, por conta dos portugueses, como bem se depreende das seguintes frases:

“... os índios não são homens em estado natural e não são selvagens, mas sim homens que retrocederam ao estado de selvageria, porque foram rechaçados violentamente do ponto a que haviam chegado. Guerras sangrentas e vinganças cruéis manti. veram, durante séculos, esses povos num estado de embrutecimento que não pode ser o da natureza, o qual supõe a existência de uma liberdade de desenvolvimento físico e intelectual. Quanto à civilização européia, para julgar de seus resultados, fora necessário que os portugueses tivessem tentado realmente implantá-lá. o que só aconteceu muito raramente e muito recentemente. Os portugueses limitaram-se a destruir a civilização que encontraram, como destruíram as próprias tribos. $O$ estado atual dos índios não pode portanto levar-nos a nenhuma conclusão acerca de suas apti. dões assimiladoras" (22).

A seguir, o autor lembra o grau de civilização que os naturais do continente americano atingiram no Peru e na Colômbia, mas acha também que não caberia a comparação entre a civilização do Peru e a européia, já que para tal seria talvez necessário

"um juiz estranho a ambas as regióes, pois, de um lado, as aparências brilhantes poderiam perturbar-nos e nos fazer superestimar a primeira, e, de outro, nossas prevenções, nossos preconceitos europeus, nos impediriam de julgar imparcialmente" (23).

Bem se vê que se trata de uma imagem não ontológica, mas fenomenologicamente negativa, como, aliás, o seria também a que nos foi dada por von Martius.

Uma indagação muito natural e, pois, facilmente previsível diante do que vem. aqui exposto diz respeito à razão pela qual esta discussão se concentra na imagem negativa e detratora do índio, em de-

(20). - Ibidem.

(21) , - Ibidem.

(22). - Op. cit., págs. 65-66.

(23) : - Ibidem. 
trimento dos retratos positivos, que sempre existiram paralelamente e que tiveram, como já foi dito, a sua primeira manifestação na chamada "certidão de nascimento do Brasil", a carta de Pero Vaz de Caminha. E fácil, porém, justificar ou, pelo menos, explicar esse realce, à primeira vista talvez estranhável. Afinal, o índio bom, inucente, fidalgo, heróico, leal e impregnado de quantas qualidades e virtudes impressionam o branco não é uma figura cunhada com vistas à comprensão do gentio em carne e osso que vive e sofre os seus problemas no íntimo das florestas ou em qualquer parte do sertão. E uma concepção que tem as suas raízes nos interesses do branco, no intuito de erigir um aborígine idealizado e, sejamos francos, por vezes falsificado em símbolo de valores nacionais e, por vezes, segundo as conveniências, em brasão de família, quiçá em substituição a algum antepassado de origem africana, menos cômodo para o traçado do quadro genealógico. O certo é que esse índio, com a sua aura de herói nacional, pouco tem significado para minorar a angústia e os sofrimentos dos que sabem, pela experiência quotidiana, o que representa o convívio com os brancos, que, aliás, nem sempre o são, mas que por motivos irracionais pretendem sê-lo, apenas para com maior eficiência firmarem a sua supremacia e a sua hegemonia sobre os pobres indígenas.

Em suma, a imagem romântica, que tão grande relevo teve na história literária e artística do século passado, nada mais foi do que uma criação, por assim dizer, para uso interno do branco em busca de uma identidade étnica nacional, em oposição à portuguesa, que recordava o peso e as pressões do antigo domínio metropolitano. Tampouco, diga-se de passagem, o especial interesse que os mentores do modernismo da década de 20 dispensaram ao índio - hajam vista, por exemplo, o Manifesto Antropófago (tupí or not tupí) de Oswald de Andrade, o Manifesto da Anta, o Macunaíma de Mário de Andrade - ficou restrito praticamente ao âmbito intelectual e artístico. Rejeitavam esses jovens o que diziam ser "o índio da lata de goiabada" - e substituíram-no por outro mito.

Por uma singular ironia da história, foram antes certos pronunciamentos de menosprezo e de repúdio pelo gentio que vieram dar alento à campanha que em fins do século passado se iniciara para conseguir que o Governo da República afinal chamasse a si a responsabilidade de criar um órgão oficial para a defesa do silvícola. Foi a primeira vez, desde a queda do Império, que as tribos brasileiras tiveram definidos em lei os seus direitos. E, paradoxalmente, foi sobretudo graças à celeuma desencadeada pelas idéias de um Hermann von Ihering que a medida chegou a concretizar-se. Como vimos, afirmara este cientista ser o índio indomável ou, pelo menos, incapaz de tornar-se elemento útil ao desenvolvimento da Nação, aconselhan- 
do, por isso, o extermínio dos que, em suas terras, opunham resistência ao avanço da civilização. A ira sagrada com que intelectuais e outros cidadãos reagiram contra essa atitude serviu para mobilizar a opinião pública e induzir o Governo a encaminhar, embora tardiamente, uma solução para o problema indígena.

Sobretudo pelos esforços de Rondon e de seus colaboradores configurou-se nessa época uma nova imagem oficial do índio. Um conceito oficial ou jurídico do índio existira, é claro, desde os primeiros tempos da Colônia, continuamente sujeito, porém, a mudanças $e$ redefinições, de acordo com as vicissitudes da vida política, esta por sua vez vinculada ao vaivém dos interesses econômicos e sociais. Menos nos atos legislativos, em que se alternavam as mais diversas modalidades do estatuto jurídico do aborígine, do que em sua execução, a imagem oficial do índio era quase sempre concebida em termos unilaterais, isto é, do ponto de vista dos desígnios e das conveniências da sociedade dominante e em prejuízo, pois, de uma solução justa e humana dos problemas vividos pelo homem das selvas. Além do mais, o retrato, ou melhor, os retratos que deste transparecem nos textos da Leis sofrem do mal da linguagem fria em que, inevitavelmente, se vaza o Direito institucionalizado. Embora se diga ser a Lei feita para os homens, e não os homens para a Lei, esta é, por natureza, insensível a inúmeros problemas concretos e imediatos que melhor se resolveriam por uma casuística do que por definições abstratas de caráter geral. Ante a complexidade da questão indígena, os artigos e os parágrafos correm muitas vezes o perigo de, na prática, redundar em letra morta.

Quanto à imagem concebida pelos missionários e que durante quatro séculos norteou a catequese cristã, ela por sua vez tomou diferentes matizes, quer de acordo con as circunstâncias históricas, quei pelo espírito próprio de cada uma das ordens e congregações religiosas empenhadas na conversão do silvícola. Ademais, os métodos e as técnicas da catequese variavam com a origem étnica dos missionários e com a formação por eles recebida nos respectivos centros europeus. Não obstante, apesar de tudo o que os distinguiia, mantiveram, de modo geral, pelos séculos afora, um objetivo bastante ben definido. Thales de Azevedo, estudando principalmente a ação dos jesuítas no período colonial, escreve que

"adotavam como modelo o catolicismo europeu mediterrâneo e as instituições políticas e econômicas dessa área" (24).

(24). - AZEVEDO, 1966, pág. 164. 
Em maior ou menor grau, mutatis mutandis, isto vale para toda a obra missionária que a Igreja desenvolveu no. Brasil.

Não vamos deter-nos aqui com a análise dos resultados dessa obra. Mas é preciso assinalar que nos últimos anos os missionários, pelo menos os de credo católico, dedicados à catequese do gentio vêm submetendo a sua atuação a um salutar exame crítico. Em parte, pela evidência dos erros do passado. A despeito das melhores intenções, apesar de seu idealismo e de muitos sacrifícios, não lograram transformar os índios nos cristãos que deles se haviam proposto fazer. $\mathrm{Na}$ maioria dos casos, a catequese religiosa em seus moldes tradicionais - tal como, aliás, a chamada catequese leiga - não deixou de produzir, a seu modo, índios ora mais, ora menos marginalizados. E não obstante a assistência sanitária, a ajuda econômica e mais benefícios, em muitas missões o declínio demográfico e os fenômenos de desorganização não ficaram aquém do que se verificou em outros grupos. Não seria difícil arrolar numerosos testemunhos de missionários que exprimem a sua decepção, o contraste entre o que pretenderam e o que puderam realizar. Há exceções, que também serịa fácil enumerar, mas elas não bastam para eliminar o problema.

A tomada de consciência, hoje cada vez mais viva, dos missionários foi estimulada em parte também por uma nova atitude da Igreja diante do sentido da catequese em geral. No Brasil, deu origem a uma revisão bastante profunda, para não dizer radical, dos objetivos . $\mathrm{E}$ com isto se esboçam os contornos de uma nova imagem missionária do índio com vistas ao futuro. Seria prematuro tentar uma descrição dessa imagem, que ainda não se definiu à semelhança, por exemplo, da que orientou a obra dos jesuítas do século XVI, quando aqui chegaram confiantes na conversão integral do gentio a um Cristianismo de estilo europeu. Este era sem dúvida o sentido das palavras de Nóbrega, quando escreveu: "Esta terra é a nossa empresa". A tolerância de práticas indígenas consideradas menos ofensivas ao espírito cristão era um recurso estratégico para facilitar ao silvícola o passo da vida pagã para o Cristianismo. E foi mais ou menos neste espírito que se veio processando a catequese até os nossos dias.

O que hoje se observa, pelo menos como propósito, é algo bem diferente. Em setembro de 1971, por exemplo, a Conferência Nacional dos Bispos do Brasil publicou o Plano Orgânico da Pastoral da Amazônia, documento que estabelece novas diretrizes. São princípios decididamente revolucionários, no plano teórico e abstrato. Até que ponto a realidade virá coresponder a essa mudança de perspectiva é coisa que o futuro dirá. Lê-se 1:o documento da CNBB: 
"Urge rever as atividades dos que trabalham entre indígenas e corrigi-las, no sentido de partir dos valores culturais e religiosos, e sociais dos indígenas para encaminhar um processo de crescimento cultural, evitando sincretismos" (25).

E, mais adiante:

"encaminhar trabalhos para estruturar a Evangelização dos indígenas, baseando-se no axioma de que a Mensagem Cristã deve encarnar-se na cultura daquele povo e não deve ser vinculada apenas com a roupagem europeizada" (26).

Com essa declaração, cabe reconhecê-lo, a Igreja se antecipou ao que iria ser a linha mestra da Lei no 6.001, de 19 de dezembro de 1973, que dispõe sobre o Estatuto do Índio. Mas cá e lá fica aberta uma questão fundamental, que não seria honesto escamotear e para a qual se deve buscar uma solução, se não quisermos que se continue perdendo muito do esforço que se envida honestamente em prol dos últimos índios que existem neste País. Com referência ao citado Plano Orgânico da Pastoral da Amazônia — onde se declara ser preciso acabar

"de uma vez por todas com a mentalidade herdada de que tudo o que é do índio "é do demônio" (27) -

o que se há de precisar em termos claros e convincentes, e não de maneira sumária e vaga, é a idéia da compatibilidade entre os valores responsáveis pelo ethos de uma cultura tribal, de um lado, e a mensagem cristã, do outro. Trata-se de saber até que ponto e de que modo esta pode encarnar-se naquela, sem quebrar-lhe a estrutura e sem ela mesma tornar-se inócua ou perder o seu sentido. E óbvio que o assunto não é apenas científico, mas também, e sobretudo, teológico, e não nos caberia, por isso, entrar aqui em sua discussão, ainda mais porque seria necessário abordá-lo à luz de recentes documentos oficiais da Igreja, que propõem uma reinterpretação da obra evangelizadora em geral. Mas não será por isso que se há de ignorá-lo.

O que, entretanto, interessa destacar é a ênfase dada a um ponto de vista que, aliás, não é novo, mas que na prática apostólica tende a cair no olvido: de que não se deve confundir a religião cristã com etnocentrismos europeus ou ocidentais. De que, ao contrário, é mais

(25). - CNBB, 1971, pág. 4.15.

(26). - Op. cit., pág. 4.17.

(27). - Ibidem. 


\section{$-335-$}

sábia e mais eficiente uma atitude de humana compreensão e de respeito diante de culturas estranhas, seja de que tipo forem.

Embora ninguém ignore que a antropologia até hoje não deu provas realmente satisfatórias do que ela poderia significar como ciência aplicada ao problema indígena brasileiro, conforta-nos em todo caso a conjetura de que as atuais concepções dos missionários foram, pelo menos em certa medida, inspiradas igualmente por critérios que hoje integram a visão que o antropólogo tem da natureza humana e da diversidade das culturas.

Neste contexto, parece oportuno invocar o testemunho de unt cientista há pouco falecido, Protásio Frikel, que dedicou sua vida em parte à tarefa missionária e em parte ao estudo intensivo de tribos indígenas, vivendo, assim, como problema de consciência, o dilema em que se encontra o missionário chamado a converter o gentio à religião cristã, sem com isso destruir o universo cultural do indígena. Não é que Protásio Frikel tenha resolvido o dilema, para o qual ninguém até hoje encontrou solução convincente, mas trata-se da opinião de um homem sério e honesto, dotado de bom senso e de espírito científico, que, não fora pela amizade que em vida lhe devotamos, mereceria a nossa atenção por suas qualidades de incansável pesquisador. Num de seus últimos trabalhos, em que a certa altura se insurge contra a intransigência etnocêntrica de certos missionários norte-americanos da fronteira do Brasil com as Guianas, um dos quais dissera não ser de seu interesse saber em que medida devem os índios ser respeitados "como povo e como seres humanos", justificando a sua posição com a assertiva:

"Nós os amamos - nós os amamos em Cristo. Nosso objetivo é o de salvar as almas. Nada mais importa",

Frikel protesta:

"Nesta última frase, 'Nada mais importa', encontra-se, ao nosso ver, a atitude mais errada dessas Missões. Não importa, então, desrespeitar grupos humanos, como se tem observado no alto Mapuera e em Kanashen? Não importa um povo em minoria perder seus costumes e tradições, adquiridos à custa de experiências de gerações e séculos? Não importa gentes de outra cultura serem consideradas 'completamente irresponisáveis, como crianças'? Mas, sem dúvida, importa, no sentido desses missionários, ser injusto e tirânico com aqueles índios, e deixar ruir toda uma cultura e mentalidade indígena, somente para implantar certos aspectos de religiosidade tipicamente americana, sobre os quais as seitas entre si também não são unânimes, resssaltando por isso especialmente 
os pontos proibitivos como são os de não fumar, não dançar, etc., o que se chama então 'salvar almas" "(28).

Deixando de lado a rixa confessional, que Frikel não superou, pergunta-se: qual seria, para ele, a atitude correta do missionário, cujo encargo não deixa de ser, em última análise, o de pregar o Evangelho a gente pagã? Diz ele:

"Reconhecemos que qualquer tipo de Missão provocará mudanças religiosas dentro do grupo indígena; poìs a catequese religiosa e, portanto, a mudança de crençás religiosas são o intuito e a finalidade de sua existência. Este aspecto, todavia, não inclui, necessariamente, interferências e mudanças na vida particular ou social do índio: pois Missão alguma tem o direito de desligar o índio de suas tradições. O cristianismo, ao nosso ver, deveria ser uma complementação das antigas crenças (por exemplo, das crenças sobre a vida no além, que também o índio possui) e, portanto, deveria ser adaptado ao ambiente e à compreensão do índio, mas não deveria constituir motivo para uma 'revolução ideológica' no seu sistema de vida" (29).

Se com esta colocação do problema não se resolve, é claro, o impasse da contradição entre doutrinas religiosas e da incompatibilidade de valores morais mutuamente exclusivos, vê-se, por outro lado, que estamos longe da concepção de que os pobres índios, em seu estado primitivo, e enquanto não recebam a mensagem evangélica. são presas de Satanás e de que as suas cerimônias religiosas tradicionais não passam de práticas inspiradas pelo Espírito das Trevas. Ou, como diria o Irmão Mateus Nogueira, um dos interlocutores do Diálogo sobre a Conversão do Gentio, de Manuel, da Nóbrega:

"são cãis em se comerem e matarem, e são porcos nos vícios e na maneira de se tratarem, e esta deve ser a rezão porque algun: Padres que do Rreino vierão, os vejo resfriados, porque vinhan cuidando de converter a todo brasil em uma hora, e vem-se que não podem converter hum em hum anno por sua rudeza e bestialidade" (30).

Cumpre fazer a ressalva de que nem todos iam a tais extrémos em sua opinião sobre os costumes e a moral indígenas e de que em numerosas passagens dos escritos deixados pelos antigos missionários se exprimem juízos menos acerbos, não raro até contrários a este.

(28). - FRIKEL, 1971, págs. 80-81.

(29). - Op. cit., págs. 103-104.

(30). - NOBREGA, 1954, pág. 54. 
Manda, ademais, o bom senso advertir que seria injusto catar nos textos jesuíticos os desabafos muito compreensíveis ante os malogros de uma catequese que, como toda empresa humana, tem os seus êxitos e os seus inevitáveis momentos de decepção.

Passemos, porém, agora para outra imagem do silvícola, a que nos propõem os homens de ciência. Dela se presume por definição que seja, na medida do possível, isenta de juízos etnocêntricos, o que não quer dizer que o cientista, ou seja, o antropólogo seja capaz de ignorar sem mais nem menos os valores que the marcam a personali.. dade. E é sabido que a antropologia teve de percorrer um longo caminho para chegar à posição que hoje se considera a mais condizente com os seus objetivos.

Basta lembrar qúe a única visão teórica de que se dispunha em todo o século XIX, a evolucionista, inspirada na tão discutível filosofia do progresso, partia do pressuposto de que os povos do Ocidente haviam conquistado o ponto mais alto das expressões culturais da humanidade, e esta era a perspectiva do antropólogo no estudo das populações tribais, supostas testemunhas vivas de estados primitivos que o homem civilizado teria atravessado em outras épocas.

Karl von den Steinen, por certo o maior dos antropólogos que no século XIX trabalharam entre índios do Brasil, exemplifica em toda a sua obra as naturais limitações inerentes a essa maneira de colocar os problemas. Apesar da isenção e da simpatia com que descreve os índios do alto Xingú, apesar do esforço de objetividade e do manifesto propósito de abster-se de juízos morais, von den Steineu não disfarça o seu orgulho de europeu civilizado ante o primitivismo dos silvícolas, nos quais procura sobretudo descobrir reminiscências dos primeiros passos dados pelo homem na evolução da cultura. Curioso e irônico é o fato de uma passagem muito pitoresca a este respeito, em seu livro sobre a primeira expedição que fez ao Brasil Central, em 1884, the haver sido inspirada por seu encontro com os Suyá, tribo muito bravia, que nunca vira gente civilizada, mas que recebeu os estranhos de maneira bastante pacífica. Um "rapaz inteligente" explicou-lhe, com mímica e palavras expressivas (tuck, tuck, tuck, wubú), como, seguindo viagem para o norte, o explorador e seus companheiros iriam, com suas canoas, precipitar-se por uma cachoeira. Altas horas da noite, deitado em sua rede e refletindo sobre o comportamento desses índios, tão bem adaptados ao meio em que viviam, o sábio, como bom europeu e como bom evolucionista, se embala no sentimento de superioridade que lhe conferem as conquistas da civilização. Exprime-o com as seguintes palavras:

"O certo é que nós mal somos capazes, ainda que em nossit fantasia, de retroceder ao estado em que vocês se encontram, e 
que, por maior que seja a benevolência com que os olhemos, nos é difícil imaginar de modo convincente que descendentes de vocês possam inventar a locomotiva e o microscópio, e muito menos a filosofia de Hegel" (31).

E óbvia, entretanto, a intenção jocosa desta frase, que, por certo. não se deve tomar ao pé da letra. Talvez o autor até acene, consciente ou inconscientemente, para a possibilidade de se inverter o seu sentido. E pelo menos o que nos fazem pensar várias passagens de suas obras, todas elas escritas sob o signo das "idéias elementares" de Adolf Bastian, um dos mentores do evolucionismo em antropologia, mas também, como outros evolucionistas da época, precursor, de modo potencial, de pontos de vista hoje aceitos por funcionalistas e até estruturalistas. De mais a mais, o discípulo de Bastian não haveria de duvidar de que o índio do Brasil central, como qualquer representante da espécie, tinha aberto, diante de si, o caminho para as conquistas da civilização, conquistas que seriam feitas pouco a pouco no decorrer do processo evolutivo, contanto que não viesse a ser perturbado por fatores estranhos ao curso normal. Também para von den Steinen, o índio, embora a sua cultura seja "pobre" e "primitiva", não é intrinsecamente incapaz.

"Nós", ós europeus, diz ele, "que somos alguns milênios mais inteligentes do que vocês", dependemos de tal modo dos elementos da civilização que "mesmo neste triste sertão trazemos conosco a bússola, pólvora, a espingarda, facas, livros, e sem eles nos sentiríamos miseráveis e até perdidos" (32).

Mais do que esta concessão dificilmente se esperaria de um antropólogo evolucionista do século passado.

Seria ocioso insistir em que também o positivismo, filosofia que postula, entre outras coisas, a lei dos três estados como sequiência de todas as culturas, se filia às correntes evolucionistas. Com relação aos destinos do índio brasileiro, a imagen positivista, antes filosófica do que propriamente científica, foi bem mais decisiva do que os conceitos que os demais evolucionistas, interessados apenas em colher dados em apoio de sua teoria, chegaram a desenvolver. Enquanto os antropólogos da estirpe não viam nos silvícolas nada mais do que material para a ciência, assim como o zoólogo que estuda o tatu, os positivistas usaram os seus princípios filosóficos para alicerçar uma

(31). - VON DEN STEINEN, 1886, pág. 203.

(32). - Ibidem. 
ideologia e até um credo religioso, a "Religião da Humanidade", no qual se deu destaque à idéia das relações fraternas entre os povos. $E$ foi graças a este postulado moral e religioso que os positivistas brasileiros conseguiram imprimir à politica indigenista oficial os rumos que iria seguir a partir da criação do Serviço de Proteção aos Indios, em 1910. 'Teve isto, sem dúvida, uma desvantagem: a de se ignorar por muito tempo a contribuição que o conhecimento antropológico poderia dar para uma solução mais racional de muitos problemas. Mas teve também o mérito de se estabelecerem desde logo normas para uma ação humanitária que se revelariam eficientes na fase heróica do Serviço de Proteção aos Indios. Já ninguém precisa realçar o fervor e o idealismo com que toda uma geração de positivistas secundada, aliás, por homens de boa vontade alheios ao sistema ideológico por eles defendido - conseguiu, em muitas regiões do País, acabar com os massacres dos indígenas.

Ora, qual é a imagem que do índio propõem os positivistas? Para não nos alongarmos demais, vejamos as palavras de um positivista de nossos dias, Paulo Carneiro, cujo pai, Mário Barbosa Carneiro, foi um dos que se empenharam, nos idos de 1910, por que fosse confiado a Cândido Mariano da Silva Rondon a chefia do órgão oficial incumbido da pacificação e da catequese leiga dos indígenas. Numa conferência feita em 1945, diz Paulo Carneiro:

"A vida espiritual dos silvícolas do Brasil, ao alvorecer do século XVI, reduzia-se às noções e aos ritos do mais puro feiticismo, refletindo, por vezes, algumas de suas lendas e instituições, formas e tendências astrolátricas. - Nesse estado inicial de civilização, irmana-se a alma indígena, por um irresistivel impulso, a tudo o que o cerca, e empresta aos seres de toda a natureza os seus próprios atributos. Tudo o que o rodeia, vive, pensa e sente como ela, comparte o seu amor ou a sua desafeição, inspira confiança ou terror, transmite qualidades boas ou más, protege ou põe em perigo... A conduta do índio, em qualquer circunstância, traduz essas disposições intelectuais e morais comuns à infância de todos os povos e pelas quais, também nós, sem exceção, passamos em certo momento de nossa evolução indivi. dual. O índió é uma criança grande, e toda criança, por mais adiantada que seja a civilização em que surge, é sempre, em determinado período, um pequeno índio... As funções cerebrais dominantes num e noutro são as mesmas e coincidem, tanto os seus defeitos, como as suas qualidades" (33).

(33). - CARNEIRO, 1946, pág. 144. 
Temos aqui em essência e em resumo o perfil do índio tal como foi traçado, repetidas vezes, no princípio do século, por Cândido Rondon e pelos que com ele batalharam. O que desde logo o caracteriza é o intuito de apresentar o silvícola como ser humano que, embora "infantil" e atrasado em sua evolução, merece respeito e tratamento condigno. E um retrato que procura, acima de tudo, levar à compreensão simpática do índio como homem em última instância igual a todos os demais, um retrato que desconhece os preconceitos que o pintam como feroz e indomável, mas que tampouco descamba para exageros de idealização romântica. E era disso que se precisava para compreender a realidade. Não importa que a visão não se coadune bem com imagens científicas que hoje nos parecem mais acertadas.

A tarefa do antropólogo é, em primeiro lugar, fazer ciência. Incumbe-lhe renovar constantemente, à medida que se desenvolvem as teorias e os métodos e se enriquece o conhecimento dos fatos, o en. tendimento científico de seu objeto de estudo. Não admira, pois, que a imagem antropológica do índio se apresente com múltiplas variantes, sempre sujeitas a modificar-se. Aspectos tidos como fundamentais em determinada perspectiva teórica se revelam de secundário interesse ao antropólogo filiado a outra corrente. O que interessa é quẻ a descrição dos fatos e a sua interpretação levem a marca da maior objetividade possível. Para não compor uma imagem pseudocientífica, impõe-se, pois, ao antropólogo - - e isto deveria ser tido como óbvio - o esforço permanente de evitar as distorções produzidas por sua maneira pessoal de ver as coisas. Deve o cientista, enquanto tal, renunciar a juízos que outro amparo não tenham senão o de uma posição filosófica, religiosa ou ideológica qualquer. Se os perfis antro-: pológicos do silvícola obtidos com a preocupação honesta de levar em conta apenas os postulados da ciência não tardam a tornar-se obsoletos, de modo que em menos de uma geração o leitor os descarta com soberano e complacente sorriso, o que não dizer dos retratos muito vivos e humanos, sem dúvida - cujo quadro de referência se reduz a um sistema, sempre dogmático, de idéias e valores religiosos e políticos ou talvez, o que é pior, a um simples conjunto de opiniões pessoais? Ninguém há de esperar em sã consciência que alguém que não perfilhe essas opiniões ou não seja adepto da respectiva corrente considere válida e verdadeira, para si como para os demais heterodoxos, a caracterização que se lhe propõe. Não é com um ato de fé que se aceita a verdade científica.

Sem embargo, a antropologia como "ciência pura" é apenas uma concepção, uma construção ideal. Notoriamente, não existe na realidade. Pelo fato de ser o homem o objeto de estudo, terá sempre algo de utópico. E é bom que assim seja. 
Há o perigo de o antropólogo - cioso de manter o espírito científico, do qual, para ser levado a sério, não pode abdicar omitir-se quanto às funções que o conhecimento objetivo é chamado a desempenhar na sociedade. Não será por sua qualidade de cientista que o estudioso dos fenômenos sociais e culturais se há de esquecer de que, afinal de contas, o seu trabalho deve ser útil aos homens, contribuir para a solução dos problemas que os afligem e para melhorar, como hoje se costuma dizer, a sua qualidade de vida. A' imagem científica do índio não é, portanto, uma imagem fria, marcada pela indiferença e pela insensibilidade de quem a elabora. As antigas teorias antropológicas, de cunho mais naturalista do que humanista, terão favorecido quiçá em certos pesquisadores uma atitude de relativo desinteresse, e, como já se disse, "absenteísta" anie a situação do indígena brasileiro. Mas desde que se começou a estruturar, em diferentes sentidos, uma teoria de antropologia aplicada, longe ainda de um grau. satisfatório de consistência e solidez, o antropólogo já não tem o direito de silenciar sobre as eventuais possibilidades de se utilizarem os resultados de suas pesquisas e análises no estabelecimento de normas de ação. De mais a mais, diga-se de passagem, o índio, que se submete pacientemente ao papel, às vezes penoso, de objeto de estudo, faz jus pelo menos a que o cientista procure ajudá-lo em suas dificuldades.

O assunto é, todavia, mais complexo. Ainda não se encontrou a fórmula para superar o divórcio entre a antropologia e a ação indigenista. Quanto a isto, impõe-se preliminarmente um protesto que, aliás, já fiz em outra ocasião - contra a reiterada e leviana assertiva de que os estudiosos das culturas e sociedades aborígines do Brasil não tenham, de modo geral, tomado consciência de suas obrigações sociais e humanas. Não é o caso de enumerar os antropólogos que, imbuídos de indignação e espírito de revolta, denunciaram sempre as injustiças e arbitrariedades cometidas contra os indígenas Vejam-se, entre outros, os livros, os artigos e os relatórios de Curt Nimuendajú, de Herbert Baldus, de Harald Schultz, de Protásio Frikel - para fazer menção somente de alguns dos que já não estão entre nós. Em geral, as suas denúncias e as suas sugestões, os seus desesperados apelos, eram simplesmente ignorados, ora por incúria ou má-fé, ora pela ignorância de certos responsáveis pela política indigenista incapazes de compreender o que se pretendia.

Tempos houve em que o cientista era tido como estorvo na política indigenista. Para muitos funcionários do Serviço de Proteção aos Indios chegava a ser um espantalho. Alijava-se o antropólogo como figura petulante, inútil, importuna e tristemente alheia à realidade, ou, quando não havia como impedir a sua presença, fa- 
ziam-se ouvidos moucos ao que se aventurasse a dizer. Os seus relatórios, bem guardados numa pasta de documentos que ninguém mais leria, tinham como destino certo o arquivo morto da repartição.

Agora, ao que tudo indica, a situação se esboça mais promissora. Percebe-se o empenho de conjugar a imagem oficial do índio com a científica. Isto não se fará, evidentemente, de um dia para outro. Mas o que de auspicioso se registra é que já se reconhece a inevitável falência, na política indigenista, de projetos e programas baseados no empirismo e na rotina. Já se presta atenção ao que a ciência talvez tenha a dizer. Patrocinam-se e promovem-se pesquisas no intuito de diagnosticar as situações específicas das diferentes tribos e, assim, ter maior probabilidade de êxito com as medidas que se venham a pôr em prática.

Seria, porém, imprudente permitir que se alimentem expectativas a que a ciência não pode corresponder. Há dilemas que não se eliminam de forma cabal, nem pela antropologia, nem por definições legais, por sagazes que sejam os seus autores. O mais grave desses dilemas, desafio a quantos se preocupam com o assunto, é o de saber até que ponto se chegará a conciliar o intuito de conservar as culturais tribais, no que elas têm de genuíno e essencial, com a necessidade, imposta pela evidência histórica e que ninguém põe em dúvida, de, aos poucos, serem os indígenas integrados à comunidade nacional .

A contradição entre os dois objetivos não é, notoriamente, peculiar à situação brasileira. Assoma como o maior dos entraves na política indigenista de todos os países latino-americanos. $E$ interessante lembrar pelo menos o exemplo do México, onde, mais do que nas outras repúblicas em que ainda existem índios, administradores e cientistas desenvolveram um esforço sistemático por encontrar diretrizes válidas para uma ação indigenista eficiente. Ora, ainda recentemente um antropólogo mexicano se manifestou sobre o problema nos seguintes termos:

"O movimento nacionalista instaurado com os regimes revolucionários reivindica a cultura índia e a incorpora a suas preocupações políticas e ideológicas. O método integral de Manuel Gamio permanece como o pilar central em torno do qual se vai definir a política indigenista oficial, mas faz surgir também a contradição fundamental que não chega a ser resolvida pela ação indigenista de nossos dias: a de integrar social e economicamente o índio, por um lado, e, por outro, a de conservar a sua cultura, respeitando as suas peculiaridades. Não obstante, essas mesmas peculiaridades continuam sendo vistas como algo exótico ou irracional, ou como ainda difícil de se entender, mas que afinal de 
contas ocupa um lugar secundário ante as exigências mais urgentes impostas pela pobreza e pela exploração que sofrem" (34).

Depois desta citação, vou, contrariando as normas e a expectativa, abster-me de tirar eventuais conclusões do que foi aqui exposto. Deixo, por enquanto, a tentativa por conta dos que, como cientistas e cidadãos responsáveis, se disponham a refletir sobre os fatos e sobre os problemas.

Seria, aliás, muito ingênuo propor, em poucas palavras, uma solução qualquer. Para terminar, parece mais conveniente fazer ouvir também o principal interessado: o índio.

Numa reunião de chefes indígenas promovida por missionários católicos na Missão Cururu, em 1975, vários desses chefes deram mostras de que se estão compenetrando da importância decisiva que para o nativo terá a imagem que de si próprio ele faça, a do presente e a do futuro, para que também ele não se exima da responsabilidade que lhe cabe. Deram mostras também, pela maneira de manifestar-se, do muito que lhes falta para terem as necessárias condições psicológicas. A fim de superarem as barreiras, precisarão de ajuda, mas sem o nosso tradicional paternalismo.

A título de exemplo, ouçamos, pois, para concluir, a voz de dois dos participantes daquela assembléia, sem dar muita atenção à oposição entre a FUNAI e os missionários, a que se alude num desses discursos e que não vem ao caso.

Assim falou Txibaibou, representante dos Borôro:

"Vivendo com muitos problemas. Dei a iniciativa de haver uma ou duas vezes por ano reunião de índios de todos. Pedimos ajuda Missão e FUNAI pra ver se os índios vão pra frente. FUNAI está para ajudar. Eu sinto muito esses massacres, que a gente ouve pelo rádio: maltratados, tirar terra, transferidos. Nós somos gente como o branco, pouco diferentes. Sabe menos, eles mexem com caminhão, avião. A política manda gente pra proteger o branco, mas não o índio. A autoridade está pronta pará mandar polícia quando há confusão de índio e para castigar. Quando o índio é ofendido, polícia não aparece ou muito difícil. A saúde, a FUNAI está aí para proteger. Deve ajudar tudo igual, até o nível do branco. Defender todos, não olhar só grupo mais. adiantado. Os missionários estão defendendo os índios, mas a FUNAI é que deveria fazer. Os padres não foram feitos para

(34). - MEDINA, pág. 120. 
ajudar índio, mas ajudam melhor que a FUNAI. Entrosamento com branco não é bom. Conserva-se índio, embora civilizado. Viver na nossa aldeia. Não deixar de ser índio. Somos os primeiros aqui dessas terras, não nós, mas nossos avós. O índio tem sentido diferente: transferir indio é judiar, é matar. Prestigiar índio, não é bicho, índio é sensível. Transferir Krenankaróre é um crime. Galibí (aparteando): Quando chegar português na Bahia encontrar nós gente: não tem rabo! Não gado. Somos tratados como os negros tratam o gado. Segue o Borôro: Os que ainda não têm problema de terra vão ter, é preciso garantir primeiro. Passar uma estrada em cima de uma aldeia é um crime. Por que não desviar? O Brasil é muito grande. Isso é triste" (35).

E, por fim, a palavra de Wayrotsú, chefe de um grupo xavánte:

"Eles já souberam o que eu disse ontem no grupo. Assunto terra, estrada não fazer confusāo na área nova. $O$ assunto de ontem eu disse uma coisa para eles porque eles quer saber alguma coisa. O Estatuto dos Indios. Lá está escrito: crime contra índio, nós não vivemos só um dia. Viver amanhã. Eles podem contar pro filhos sobre o progresso. Falei sobre a cultura dos indios. Os brancos não podem abusar, não pode brincar com cultura. Se branco oferece cachaça, ele tem direito de ficar na cadeia, porque dá estrago e é ruim para os índios. Se abusar das mulheres, pode ficar na cadeia. Eles não podem ler jornal, por isso eu contar para eles. O que é importante é a nossa vida, o nosso costume, não podemos deixar para pegar as coisas do branco. Nós temos tudo. Não perder. Lembrar pra não perder o nosso costume. Senão a ruína vem, a destruição acabar o índio. Porque nós é assim a nossa vida, porque nós não podemos viver no meio dos branco, não vivemos só um dia, precisamos um chão, um pedaço de terra, não tudo, só pedaço. Pedimos ao Presidente da FUNAI socorro pra sair a terra. Estamos esperando a promessa. Tantos anos assim mesmo. A nossa vida é curta. Já ouvi falar tanto, ouvi falar que vão sair no fim do mês. Vamos ver. Se não sair, vamos a Brasília. Diz o jornal: a paciência do índio é curta" (36).

(35). - 2a Assembléia de Chefes Indígenas, pág. 41.

(36). - Op. cit., págs. 37-38. 


\section{BIBLIOGRAFIA.}

AZEVEDO, Thales de

1966. Cultura e Situação Racial no Brasil. Editora Civilização Brasi leira S.A. Rio de Janeiro.

CARDIM, Fernão

1939. Tratados da Terra e Gente do Brasil. Introduções e notas de Batista Caetano, Capistrano de Abreu e Rodolfo Garcia. $2^{\text {a }}$ edição. Coleção Brasiliana, vol. 168. Companhia Editora Na. cional. São Paulo.

CARNEIRO, Paulo

1946. "A epopéia da Missão Rondon". Em: O Dia do índio. Publicação $n^{\circ} 100$ do Conselho de Proteção aos Indios, Ministério da Agricultura. Rio de Janeiro.

CNBB (Conferência Nacional dos Bispos do Brasil)

1971. Plano Orgânico da Pastoral da Amazônia. Edição mimeografada.

COELHO DOS SANTOS, Sílvio

1975. Educação e Sociedades Tribais. Editora Movimento. Porto Alegre.

FRIKEL, Protásio

1971. Dez Anos de Aculturação Tiriyó: 1960-70: Mudanças e Problemas. Publicações Avulsas, $\mathrm{n}^{\circ}$ 16. Museu Paraense Emílio Goeldi. Belém.

VON IHERING, Hermann

1907. "A antropologia do Estado de São Paulo". Revista do Museu Paulista, vol. 7\%, págs. 202-257. São Paulo.

MAGALHȦES, D. J. G.

1860. "Os indígenas do Brasil perante a História". Revista Trimensai do Instituto Histórico, Geográfico e Etnográfico do Brasil, tomo XXIII, págs. 3-66. Rio de Janeiro.

VON MARTIUS, Carl Friedrich Phil.

1867. Zur Ethnographie Amerikas, zumal Brasiliens. Friedrich Fleischer Verlag. Leipzig.

MEDINA, Andrés

1974. "Etnología o literatura? El caso de Benítez y sus índios". Anales de Antropología, vol. IX, págs. 109-40. México. 
MELO FRANCO, Afonso Arinos de

1937. O Indio Brasileiro e a Revolução Francesa. As Origens Brasileiras da Teoria da Bondade Natural. Coleção Documentos Brasileiros, vol. 7. Livraria José Olympio Editora. Rio de Janeiro

NOBREGA, Manuel da

1954. Diálogo sobre a Conversão do Gentio. Com preliminares e anotações históricas e críticas de Serafím Leite, S. J. Lisboa.

OTÃVIO, Rodrigo

1946. Os Selvagens Americanos Perante o Direito. Coleção Brasiliana, vol. 254. Companhia Editora Nacional. São Paulo.

PORTO SEGURO, Visconde de

s. d. História Geral do Brasil Antes de sua Separação e Independência de Portugal. 4a edição. Tomo 1. Companhia Melhoramentos de de São Paulo. São Paulo.

RUGENDAS, João Maurício de

1940. Viagem Pitoresca Através do Brasil. Tradução e notas de Sérgio, Milliet. Biblioteca Histórica Brasileira, vol. I. Livraria Martins. São Paulo.

SCHADEN, Egon

1974. The Image of the Brazilian Indian. Conferência pronunciada na Universidade de Toronto. Manuscrito (no prelo).

$2^{a}$ Assembléia de Chefes Indígenas. Missão Cururu. 8-14 Maio 1975. Sem data e sem lugar.

VON DEN STEINEN, Karl

1886. Durch Central-Brasilien. F. A. Brockhaus. Leipzig.

\section{VĀRIOS AUTORES}

1950. Centenário de Blumenau. Comissão de Festejos. Blumenau. 